\title{
Copper Cu 64-DOTA-AE105
}

National Cancer Institute

\section{Source}

National Cancer Institute. Copper Cu 64-DOTA-AE105. NCI Thesaurus. Code C116075.

A radiotracer composed of AE105, a urokinase-type plasminogen activator receptor (UPAR) peptide antagonist, conjug ated with DOTA and labeled with the radionuclide copper Cu 64, with potential imaging activity upon positron emission tomography (PET). Upon administration, the AE105 moiety of copper CU 64-DOTA-AE105 targets and binds to uPAR-expressing tumor cells. Upon PET imaging, the copper Cu 64 moiety can be visualized, UPAR-expressing tumor cells can be quantified and the degree of tumor aggressiveness can be assessed. UPAR expression is correlated with increased tumor invasiveness and aggressiveness as well as a poor prognosis. 